Pesq. Vet. Bras. 35(4):349-352, abril 2015 DOI: $10.1590 /$ S0100-736X2015000400006

\title{
Occurrence of Campylobacter jejuni and $C$. coli on broiler carcasses after chilling in southern Brazil ${ }^{1}$
}

\author{
Gustavo Perdoncini ${ }^{2}$, Yuli M. Sierra-Arguello², Leonardo M. Lima², Michele M. \\ Trindade $^{2}$, Marcos José Pereira Gomes ${ }^{2}$, Luciana R. dos Santos ${ }^{3}$, Verônica Schmidt ${ }^{4}$ \\ and Vladimir Pinheiro do Nascimento ${ }^{2}$
}

\begin{abstract}
Perdoncini G., Sierra-Arguello Y.M., Lima L.M., Trindade M.M., Gomes M.J.P., Santos L.R., Schmidt V. \& Nascimento V.P. 2015. Occurrence of Campylobacter jejuni and C. coli on broiler carcasses after chilling in southern Brazil. Pesquisa Veterinária Brasileira 35(4):349-352. Centro de Diagnóstico e Pesquisa em Patologia Aviária, Faculdade de Veterinária, Universidade Federal do Rio Grande do Sul, Av. Bento Gonçalves 8824, Porto Alegre, RS 91540-000, Brazil. E-mail: gustavo.perdoncini@yahoo.com

Campylobacter jejuni and C. coli have been associated with gastrointestinal disorders in human beings, due mainly to the consumption of chicken meat. Despite control measures for reducing contamination by these bacteria, the detection of Campylobacter in carcasses after chilling remains high. A total of 105 carcasses were assessed by the horizontal detection method in five federally inspected slaughterhouses in southern Brazil in 2012 and in the first three months of 2013. Campylobacter was isolated in $37.1 \%$ of the carcasses, of which $97.5 \%$ contained $C$. jejuni and $2.5 \%$ were infected by $C$. coli. The rate of positive carcasses across the slaughterhouses ranged from 0 to $71.4 \%$. Determining the occurrence of Campylobacter among flocks is crucial for estimating the microbial load at specific points along the slaughtering process and for minimizing the risk of contamination of end products by Campylobacter.
\end{abstract}

INDEX TERMS: Campylobacteriosis, cross-contamination, broilers, zoonosis.

RESUMO.- [Campylobacter jejuni e C. coli em carcaças de frangos após a refrigeração por imersão no sul do Brasil.] Campylobacter jejuni e C. coli têm sido associados a problemas gastroentéricos em seres humanos principalmente devido ao consumo de carne de frango. Embora medidas de controle sejam realizadas para reduzir a contaminação por estas bactérias, a identificação de Campylobacter em carcaças após a refrigeração por imersão é alto. Foram analisadas 105 carcaças pelo método de detecção horizontal em cinco abatedouros sob Inspeção Federal no sul do Brasil em 2012 e nos três primeiros meses de 2013. Campylobacter foi isolada em $37,1 \%$ das carcaças analisadas,

\footnotetext{
${ }^{1}$ Received on September 16, 2014.

Accepted for publication on April 9, 2015.

${ }^{2}$ Centro de Diagnóstico e Pesquisa em Patologia Aviária (CDPA), Faculdade de Veterinária, Universidade Federal do Rio Grande do Sul (UFRGS), Av. Bento Gonçalves 8824, Porto Alegre, RS 91540-000, Brazil. *Corresponding author: gustavo.perdoncini@yahoo.com

${ }^{3}$ Faculdade de Veterinária e Agronomia, Universidade de Passo Fundo (UPF), BR-285 Km 171, Cx. Postal 611, Passo Fundo, RS 99001-970, Brazil.

${ }^{4}$ Faculdade de Veterinária, UFRGS, Av. Bento Gonçalves 9090, Porto Alegre, RS 91540-000.
}

as quais $97,5 \%$ foram identificados como $C$. jejuni e $2,5 \%$ como $C$. coli. A ocorrência de carcaças positivas entre matadouros variou de zero a 71,4\%. O conhecimento sobre a ocorrência de Campylobacter entre os lotes é fundamental para estimar a extensão da carga microbiana em pontos específicos do abate e consequentemente minimizar o risco de contaminação por Campylobacter em produtos finais de frangos.

TERMOS DE INDEXAÇÃO: Campilobacteriose, contaminação cruzada, frangos, zoonose.

\section{INTRODUCTION}

Thermotolerant Campylobacter spp. are the causative agents of campylobacteriosis (Rosenquist et al. 2003, Butzler 2004), a zoonotic disease (WHO 2000) transmitted to human beings mainly by the consumption of contaminated poultry products (Dickins et al. 2002). In the European Union (EFSA 2012) and in the United States (CDC 2013) Campylobacter jejuni and Campylobacter coli are often associated with gastroenteritis, and $C$. jejuni is also implicated in Guillain-Barré syndrome (Vucic et al. 2009). The rise 
in the incidence of campylobacteriosis in several countries, especially after 1990, has caused a lot of concern due to the growing morbidity and mortality rates among children and immunocompromised individuals (WHO 2000). This has encouraged research studies in an attempt to minimize the number of positive flocks and to have a better understanding of the intrinsic characteristics of these bacteria.

Seeking to reduce the impact of this pathogen on public health, research studies have investigated the factors that contribute to contamination and persistence of Campylobacter spp. on poultry farms. The direct contact of birds with feces, untreated water, rodents, wild birds, or vectors such as Alphitobius diaperinus (darkling beetles) infected with this bacterium may contaminate the flocks to be slaughtered (Eberle et al. 2013).

At meat-packing plants, contaminated feces and feathers help disseminate Campylobacter in the slaughtering process. Defeathering is critical for contamination as the concentration of Campylobacter increases at this stage, as well as in evisceration (Herman et al. 2003, Rosenquist et al. 2006, Figueroa et al. 2009), and measures such as rinsing and chilling of carcasses are alternatives for reducing the incidence of Campylobacter (Reich et al. 2008, Figueroa et al. 2009).

However, contamination may occur at any time during the slaughtering process, for instance, in scalding, defeathering, and chilling (Rosenquist et al. 2006, Allen et al. 2007, Figueroa et al. 2009). A study that investigated previous colonization of carcasses by Campylobacter spp. detected contamination with $C$. jejuni and $C$. coli, in broiler carcasses in two out of five previously negative flocks (Allen et al. 2007).

Given the importance of this bacterium to public health and to poultry production, this paper assesses the occurrence of $C$. jejuni and $C$. coli in broiler carcasses after chilling at meat-packing plants in southern Brazil.

\section{MATERIALS AND METHODS}

A cross-sectional observational study was conducted and convenience samples were used (Thrusfield 2004). In total, 105 broiler carcasses were collected after chilling from five federally inspected slaughterhouses in southern Brazil in 2012 and in the first three months of 2013. The samples were stored in isothermal ice boxes and taken to the laboratory for identification of $C$. jejuni and C. coli by the horizontal method (ISO 10272-1:2006). The chilled carcasses were rinsed in sterile polyethylene bags containing 400 $\mathrm{mL}$ with buffered peptone water $\left(\mathrm{Oxoid}^{\circledR}\right)$ and aliquots of $1 \mathrm{~mL}$ were obtained and homogenized in $9 \mathrm{~mL}$ of Bolton broth - Oxoid ${ }^{\circledR}$ (1:9), which were then incubated in a microaerophylic environment $\left(5 \% \mathrm{O}_{2}, 10 \% \mathrm{CO}_{2}\right.$ and $\left.85 \% \mathrm{~N}_{2}\right)$ at $41.5 \pm 0.5^{\circ} \mathrm{C}$ for 48 hours. Thereafter, $100 \mu \mathrm{L}$ of the broth suspension was filtered in acetate membrane measuring $0.65 \mu \mathrm{m} \times 47 \mathrm{~mm}$ (Skirrow 1977, Bolton 1982) plated onto mCCD agar (CM739, Oxoid $^{\circledR}$ ) for 30 minutes, followed by incubation under the conditions described earlier. Campylobacter-compatible colonies were grown on $7 \%$ sheep blood agar.

For positive control of isolation and PCR assays were used two references strains, C. jejuni subsp. jejuni ATCC 29428 and C. coli ATCC 43478. The negative control for PCR assay was used Arcobater sp. strain.

The DNA of the colonies was obtained by thermal extraction and used for multiplex PCR as proposed by Denis et al. (1999) with some changes, which allows distinguishing $C$. jejuni from $C$. coli. Three primer pairs were used for each reaction, based on the sequence of primers for the common 16rRNA region between the species: MD16S1, (16S rRNA) $F^{\text {a }}$ - ATCTAATGGCTTAACCATTAAAC e $R^{\mathrm{b}}$ - GGACGGTAACTAGTTTAGTATT with $857 \mathrm{pb}$. The identification of $C$. jejuni and $C$. coli was based on the genes mapA $F^{\text {a }}$ - CTATTTTATTTTTGAGTGCTTGTG and $R^{\mathrm{b}}$ - GCTTTATTTGCCATTTGTTTTATTA with $589 \mathrm{pb}$ and $c e u \mathrm{E} F^{\mathrm{a}}$ - AATTGAAAATTGCTCCAACTATG and $R^{\mathrm{b}}$ - TGATTTTATTATTTGTAGCAGCG with $462 \mathrm{pb}$, respectively.

The amplification conditions were as follows: denaturation $\left(10\right.$ minutes at $\left.95^{\circ} \mathrm{C}\right), 35$ cycles of denaturation $(30$ seconds at $\left.95^{\circ} \mathrm{C}\right)$, annealing ( 1 minute and 30 seconds at $\left.59^{\circ} \mathrm{C}\right)$, extension $(1$ min at $\left.72^{\circ} \mathrm{C}\right)$, followed by final extension $\left(10\right.$ minutes at $\left.72^{\circ} \mathrm{C}\right)$. All reactions were performed in a thermocycler (Biocycler - Peltier Thermal Cycler MJ96+MJ96G) and visualized by 1.5\% agarose gel electrophoresis stained with ethidium bromide and by ultraviolet transillumination imaging.

\section{RESULTS AND DISCUSSION}

Campylobacter was detected in $37.1 \%$ of the 105 analyzed carcasses, showing prevalence of $C$. jejuni (97.5\%) followed by $C$. coli $(2.5 \%)$. Both species were detected in two samples $(5.1 \%)$.

These rates are lower than those reported for European Union countries in 2008 (EFSA 2010), where 75.3\% of chilled carcasses were positive for Campylobacter spp., with a range from $4.9 \%$ (Estonia) to $100 \%$ (Luxembourg) and detection of $C$. jejuni in $60.8 \%$ of the flocks, followed by $C$. coli and $C$. lari with $41.5 \%$. Carcasses before final rinsing may have a high incidence (up to $100 \%$ ) of Campylobacter, but contamination at this stage is significantly reduced by rinsings and later refrigeration (Son et al. 2007).

In this study the rates of Campylobacter-positive samples varied from 0 to $71.4 \%$ in chilled carcasses at the five meat-packing plants. In fact, the bacterium was not isolated from only one of the plants (Table 1). These differences can be attributed to the procedures carried out at meat-packing plants, their characteristics, quality management, and minimum operating health standards throughout the slaughtering process, indicating that any problems with these items will be closely related to the final contamination of carcasses (Habib et al. 2012). Another important factor concerns positive flocks, which influence the contamination of equipment and, consequently, the microbiological quality of the end product (Smith et al. 2007, Malher et al. 2011). Consonant with these findings, Kuana et al. (2008) assessed 22 broiler flocks and observed that only

Table 1. Occurrence if Campylobacter jejuni and C. coli at meat-packing plants and in carcasses after chilling

\begin{tabular}{lccccc}
\hline $\begin{array}{c}\text { Meat-packing } \\
\text { plant }\end{array}$ & $\begin{array}{c}\text { Positive } \\
\text { carcasses }\end{array}$ & $(\%)$ & $\begin{array}{c}\text { Negative } \\
\text { carcasses }\end{array}$ & $(\%)$ & Total \\
\hline A & $5^{*}$ & 27,78 & 13 & 72,22 & 18 \\
B & $12^{* *}$ & 50 & 12 & 50 & 24 \\
C & 12 & 57.14 & 9 & 42.86 & 21 \\
D & 10 & 71.42 & 14 & 28.58 & 24 \\
E & 0 & 0 & 18 & 100 & 18 \\
TOTAL & $39(37.14 \%)$ & & $66(62.86 \%)$ & & 105
\end{tabular}

*0ne positive sample only for Campylobacter coli; **Two positive samples for both species. The other isolates were identified as $C$. jejuni. 
four of them were not positive for Campylobacter spp. before slaughter but that changed during the processing stage with the isolation of the bacterium in chilled carcasses.

The increase in carcass contamination is often related to fowl size and to equipment setup. It should be noted, though, that even when the equipment is properly regulated, there may be intestinal rupture in broilers and contamination of the slaughter line. Two different approaches can be used for reducing and/or eliminating the bacterium: adoption of specific control measures for the reduction of Campylobacter-positive farms at the primary level, and actions for minimizing the contamination of ready-to-sell carcasses at the industry level (Hald et al. 2000).

Rinsing and refrigeration of carcasses are alternatives for controlling contamination during the slaughtering process, while the immersion of carcasses in water at $75^{\circ} \mathrm{C}$ for 30 seconds (Corry et al. 2007) or the use of vapor at $90^{\circ} \mathrm{C}$ for 12 seconds (Whyte et al. 2003) after chilling yielded Campylobacter reduction rates of $1.6 \log _{10} \mathrm{cfu} / \mathrm{cm}^{2}$ and $1.3 \log _{10} \mathrm{cfu} / \mathrm{g}$, respectively. The use of organic acids in the chilling process has been assessed and has reduced contamination, but these products have an impact on the sensory features of carcasses (Nagel et al. 2013).

Investment in logistics and verification of flocks for the presence of Campylobacter before slaughter help reduce cross-contamination (Nauta \& Havelaar 2008) and would be an alternative for avoiding putting negative and positive flocks together. Nevertheless, this strategy is not successful when traditional detection methods are used, as such methods require at least 48 hours for confirmation of positive results. Once negative flocks are identified in the field, it is necessary to ensure that broilers will not be contaminated during transportation from the farms to the slaughterhouse (Hansson et al. 2005). However, a study conducted in the Netherlands by Nauta et al (2009) assessed 62 broiler flocks and did not find significant support for the implementation of control strategies targeted at the identification of positive flocks in the field and at slaughtering time. The correlation between the contamination of feces and of breast cuts by Campylobacter suggests these assessed criteria are not good indicative signs of human exposure to Campylobacter.

Only the identification of the bacterium in the field would not be an indication of possible human campylobacteriosis, due to the influence of slaughtering technology, which makes the detection of Campylobacter in carcasses an essential tool for evaluating the risk of contamination. The adoption of measures that can reduce the number of positive carcasses goes beyond slaughtering logistics (Evers 2004), as other measures such as improvements in scalding, in the configuration of defeathering equipment and techniques, in evisceration, and additional rinsings of carcasses are also important.

The inclusion of qualitative microbiological analysis of carcasses is paramount in checking for the presence of pathogens after the processing stage. This allows estimating the microbial load at specific points along the process, thereby minimizing the incidence of Campylobacter in carcasses after chilling and improving the microbiological quality of chicken meat.
Acknowledgments.- To CNPq (Brazilian National Council for Scientific and Technological Development) and CAPES (Coordination for the Improvement of Higher Education Personnel) for the financial support and fellowship grants. We are also thank to professor Marcos José Pereira Gomes, head of the Laboratory of Veterinary Bacteriology of Universidade Federal do Rio Grande do Sul, and to the CDPA (Diagnostic and Research Center for Avian Pathology) for their technical and structural support.

\section{REFERENCES}

Allen M.V., Bull S.A., Corry J.E.L., Domingue G., Jørgensen F., Frost J.A., Whyte R., Gonzalez A., Elviss N. \& Humphrey T.J. 2007. Campylobacter spp. contamination of chicken carcasses during processing in relation to flock colonisation. Int. J. Food Microbiol. 113:54-61.

Butzler J.P. 2004. Campylobacter, from obscurity to celebrity. Clin. Microbiol. Infect. 10:868-876.

Bolton F.J. \& Robertson L. 1982. A selective medium for isolating Campylobacter jejuni/coli. J. Clin. Pathol. 35:462-467.

CDC 2013. Incidence and Trends of Infection with Pathogens Transmitted Commonly Through Food - Foodborne Diseases Active Surveillance Network, 10 U.S. Sites, 1996-2012. Morbidity and Mortality Weekly Report. 19:283-287.

Corry J.E.L., James S.J., Purnell G., Pinto C.S., Chochois Y., Howell M. \& James C. 2007. Surface pasteurisation of chicken carcasses using hot water. J. Food Eng. 76:913-919.

Dickins M.A., Franklin S., Stefanova R., Schutze G.E., Eisenach K.D., Wesley I. \& Cave M.D. 2002. Diversity of Campylobacter isolates from retail poultry carcasss and from humans demonstrated by pulse-field gel electrophoresis. J. Food Protect. 65:957-962.

Denis M., Soumet C., Rivoal K., Ermel G., Blivet D., Salvat G. \& Colin P. 1999. Development of a m-PCR assay for simultaneous identification of Campylobacter jejuni and C. coli. Lett. Appl. Microbiol. 29:406-410.

Eberle K.N., Davis J.D., Purswell J.P., Parker H.M., McDaniel C.D. \& Kiess A.S. 2013. A One Year Study of Newly Constructed Broiler Houses for the Prevalence of Campylobacter. Int. J. Poult. Sci. 12:29-36.

EFSA 2010. Analysis of the baseline survey on the prevalence of Campylobacter in broiler batches and of Campylobacter and Salmonella on broiler carcasses in the EU, 2008. Part A: Campylobacter and Salmonella prevalence estimates. Eur. Food Safety Authority J. 8:1-99.

EFSA 2012. Scientific Opinion on a review on the European Union Summary Reports on trends and sources zoonoses, zoonotic agents and food borne outbreaks in 2009 and 2010: specifically for the data on Salmonella, Campylobacter, verotoxigenic, Escherichia coli, Listeria monocytogenes and foodborne outbreaks. Eur. Food Safety Authority J. 10:1-25.

Evers E.G. 2004. Predicted quantitative effect of logistic slaughter on microbial prevalence. Prev. Vet. Med. 65:31-46.

Figueroa G., Troncoso M., López C., Rivas P. \& Toro M. 2009. Occurrence and enumeration of Campylobacter spp. during the processing of Chilean broilers. BMC Microbiol. 9:1-6.

Habib I., Berkvens D., Zutter L. De, Dierick K., Huffel X.V., Speybroeck N., Geeraerd A.H. \& Uyttendaele M. 2012. Campylobacter contamination in broiler carcasses and correlation with slaughterhouses operational hygiene inspection. Food Microbiol. 29:105-112.

Hald B., Wedderkopp A. \& Madsen M. 2000. Thermophilic Campylobacter spp. in Danish broiler production: A cross-sectional survey and a retrospective analysis of risk factors for occurrence in broiler flocks. Avian Pathol. 29:123-131.

Hansson I., Ederoth M., Andersson L., Vagsholm I. \& Olsson Engvall E. 2005. Transmission of Campylobacter spp. to chickens during transport to slaughter. J. Appl Microbiol. 99:1149-1157.

Herman L., Heyndrickx M., Grijspeerdt K., Vandekerchove D., Rollier I. \& De Zutter L. 2003. Routes for Campylobacter contamination of poultry meat: epidemiological study from hatchery to slaughterhouse. Epidemiol. Infect. 131:1169-1180.

ISO 2006. International Standard Organization 10272-1:2006 describes a horizontal method for the detection of Campylobacter spp. 
Kuana S.L., Santos L.R., Rodrigues L.B., Salle C.T.P.S., Moraes H.L.S. \& Nascimento V.P. 2008. Occurrence and Characterization of Campylobacter in the Brazilian Production and Processing of Broilers. Avian Dis. 88:680684.

Malher X., Simon M., Charnay V., Déserts R.D., Lehébel A. \& Belloc C. 2011. Factors associated with carcass contamination by Campylobacter at slaughterhouse in cecal-carrier broilers. Int. J. Food Microbiol 150:813

Nagel G.M., Bauermeister L.J., Bratcher C.L., Singh M. \& McKee R.S. 2013. Salmonella and Campylobacter reduction and quality characteristics of poultry carcasses treated with various antimicrobials in a post-chill immersion tank. Int. J. Food Microbiol. 165:281-286.

Nauta M.J. \& Havelaar A.H. 2008. Risk-based standards for Campylobacter in the broiler meat chain. Food Control 19:372-381.

Nauta M.J., Van der Wal F.J., Putirulan F.F., Post J., Van der Kassteele J. \& Bolder N.M. 2009. Evaluation of the "testing and scheduling" strategy for control of Campylobacter in broiler meat in The Netherlands. Int. J. Food Microbiol. 134:216-222.

Reich F., Atanassova V. \& Klein G. 2008. The effects of Campylobacter numbers in caeca on the contamination of broiler carcasses with Campylobacter. Int. J. Food Microbiol. 127:116-120.

Rosenquist H., Nielsen N.L., Sommer H.M., Nørrung B. \& Christense B.B. 2003. Quantitative risk assessment of human campylobacteriosis asso- ciated with thermophilic Campylobacter species in chickens. Int. J. Food Microbiol. 83:87-103.

Rosenquist H., Sommer H.M., Nielsen N.L. \& Christensen B.B. 2006. The effect of slaughter operations on the contamination of chicken carcasses with thermotolerant Campylobacter. Int. J. Food Microbiol. 108:226-232.

Skirrow M.B. 1977. Campylobacter enteritis: a "new" disease. Brit. Med. J. 2:9-11.

Smith D.P., Northcutt J.K., Cason J.A., Hinton Jr A., Buhr R.J. \& Ingram K.D. 2007. Effect of external or internal fecal contamination on numbers of bacteria on pre-chilled broiler carcasses. Poultry Sci. 86:1241-1244.

Son I., Englen M.D., Berrang E.B., Fedorka-Cray P.J. \& Harrison M.A. 2007. Prevalence of Arcobacter and Campylobacter on broiler carcasses during processing. Int. J. Food Microbiol. 113:16-22.

Thrusfield M. 2004. Epidemiologia Veterinária. Roca, São Paulo. 556p.

Vucic S., Kierman M. \& Comblath D.R. 2009. Guillain-Barré syndrome: An update. J. Clin. Neurosci. 16:733-741.

Whyte P., McGill K. \& Collins J.D. 2003. An assessment of steam pasteurisation and hot water immersion treatments for the microbiological decontamination of broiler carcases. Food Microbiol. 20:111-117

World Health Organization - WHO. Campylobacter. 2000. Disponível em <http://www.who.int/mediacentre/factsheets/fs255/en/print.html> Access in Aug. 2013. 